УДК 681.3 .05

DOI https://doi.org/10.32838/2663-5941/2021.2-1/40

Чернишов К.А.

orcid.org/0000-0002-8639-2732

Вінницький національний технічний університет

Майданюк В.П.

Вінницький національний технічний університет

\title{
Арсенюк I.P.
}

orcid.org/0000-0003-4045-6144

Researcher ID * T-9166-2017

Вінницький національний технічний університет

\section{ПРИНЦИПИ ПРОЕКТУВАННЯ СУЧАСНИХ ВЕНДИНГОВИХ СИСТЕМ}

Розкрито принщипи проектування сучасних вендингових систем. Запропоновано генезис торгових автоматів та описано різновиди їх застосування. Наведено основні види вендингових автоматів та їх устаткування. Описано принципи застосування вендингових систем у різних краӥнах світу. Запропоновано огляд можсливих станів вендингової системи та переходи між ними. Охарактеризовано універсальний дизайн сучасного вендингового автомату, в якому відокремлено апаратні та програмні компоненти. Підкреслено важливість управління оператором та запропоновано перелік основних дій, таких як: слідкування за (повторним) наповненням, очищенням та функиіональною ефективністю торгового автомата, а також за ефективністю корпусу, збирання асортименту та прийняття рішення щодо платіжної системи. Наведено схему плати вводу-виводу вендингового автомату з відокремленням фундаментальних складових. Визначено ланки з'єднання між компонентами всередині плати розширення вендингового автомату. Схематично представлено програмний стек вендингової системи, який дає наочне уявлення про функиіональну складову частину вендингової системи. Архітектура програмного забезпечення еталонного дизайну абстрагує торговий ввід-вивід, щзо дозволяє виробникам вендингових автоматів сконцентруватися на додатках високого рівня та на тому, що відображається на екрані. Зазначається, щзо даний факт досягається за допомогою двох типів АРI: API низького рівня для доступу до певних торгових протоколів вводу-виводу та АРІ високого рівня для доступу до периферійного типу, не вимагаючи від програмістів знання деталей фактичного пристрою. Підкреслено, що високий рівень АРI спрощує написання вендингової програми та може дозволити торговим операторам використовувати одну програму на всьому їх парку машин, а також обробляе зміни в протоколах, таких як MDB, і забезпечує додаткову гнучкість для адаптації до незначних змін у протоколах иини, що потрібно, коли виробники периферійних пристроїв відхиляються від стандартних специфікацій.

Ключові слова: вендинг, система, керування, моніторинг, Інтернет речей, контролер, протокол.

Постановка проблеми. Вендинг та цифрова ера Інтернет прискорює темпи інновацій та трансформує ринки, провідну роль серед яких займає вендингова галузь. Одним із прикладів цього $є$ Інтернет речей (IоT), який використовує сучасні ізольовані системи та підключає їх до Інтернету тенденція, яка вже існує для торгових автоматів. Усі вендингові машини можуть бути підключені до Інтернету, мати доступ до соціальних мереж і стати справжньою периферією, що взаємодіє в Інтернеті. У майбутньому торгові автомати матимуть значно більшу кількість функцій, пропонуючи додаткові послуги користувачам. Для виробників продуктів та операторів ця нова реальність пропонує можливості для фінансового зростання, видимості бренду, залучення клієнтів та скорочення операційних витрат. Переважну більшість машин сконструйовано 3 контролером торгових автоматів (VMC), який управляє багатьма основними підсистемами, такими як оплата, управління охолодженням та освітленням, обробка монет та продуктів тощо. Оскільки VMC, як правило, базується на мікроконтролері низького класу, йому не вистачає обчислювальної потужності, підключення, безпеки, керованості та простоти перепрограмування, необхідних для підтримки нових служб після встановлення, таких як запуск програм лояльності та маркетингові кампанії. 
Аналіз останніх досліджень i публікацій. В останні кілька років чимало як зарубіжних, так і вітчизняних вчених здійснило відкриття у сфері сучасних вендингових систем.

А.М. Сало [1] дослідила принципи побудови вендингової мережі з моніторингом, автором пропонується комп'ютерна система керування вендінговим автоматом. У роботі детально описано процес взаємодії вендінгового автомата із серверною системою. Також авторкою розглянуто особливості роботи вендингових кіберфізичних систем після тривалої експлуатації. Проаналізовано вже готові способи масштабування кіберфізичних систем. Визначено основні недоліки та переваги переходу вже готової системи на платформу стороннього розробника. Запропоновано способи оптимізації баз даних із великою кількістю інформації [2].

Н.І. Горбаль, З.Ю. Келлер та М.Б. НайчукХрущ [3] проаналізували актуальність вендингового стартапу на вітчизняному ринку та навели основні сегменти вендингу в Україні. Розглянули основні переваги при впровадженні такого стартапу для підприємця. Навели бар'єри входу на ринок і виділили приблизний розмір необхідного стартового капіталу.

О.Л. Котвицький [4] розробив модуль безготівкової оплати системи самообслуговування. Розглянено існуючі системи. Показано узагальнений режим роботи модулю безготівкової оплати та його структуру.

Із зарубіжних авторів варто відмітити роботи Vennan Sibanda, Lorraine Munetsib, Khumbulani Mpofua, Eriyeti Murenaa, John Trimblea [5], Lee E. A. та Seshia S. A. [6], Hua S.V., Ickovics J.R. [7], Gruber S. [8], Donald W. [9] та інші.

Проте, враховуючи описані наукові набутки за темою, питання дослідження принципів проектування сучасних вендингових систем залишається відкритим та потребує детального опрацювання.

Постановка завдання. Мета статті - здійснити огляд принципів проектування сучасних вендингових систем.

Виклад основного матеріалу дослідження. Перший торговий автомат був побудований Героном Олександрійським (Механік, близько 100 р. до н. е.). Після вставлення в нього монети розливалася свята вода. Більше 100 років люди не могли купувати товари та послуги у торгових автоматах. Перші вендингові автомати були побудовані в кінці 80 -х років XIX століття. 13 березня 1908 року перед готелем Des Postes було встанов- лено перший у світі торговий автомат із марками та листівками.

Вендингові автомати використовуються на різних ринках, у роздрібній торгівлі для продажу продуктів харчування та непродовольчих товарів, а також товарів першої необхідності. Раніше продаж холодних та гарячих напоїв був переважним бізнесом, але в даний час різноманітність товарів та послуг, що продаються за допомогою вендингових автоматів, неухильно зростає. Вендингові асоціації в різних країнах визначають вендинг по-різному.

В основному вендинг визначається як продаж продуктів через торгові автомати, які $є$ «монетними автоматами для продажу дрібних предметів». Крім того, торгові автомати можуть бути розроблені для продажу великої кількості різноманітних продуктів, наприклад, в Японії можна придбати десять кілограмових мішків рису з торгового автомату. Крім того, протягом декількох років можна оплачувати товари та послуги кредитною карткою, яку потрібно помістити у слот торгового автомата для карток.

Американська асоціація NAMA (Національна асоціація автоматичних товарів) заявляе, що «венд - це доставка однієї одиниці товару». У США торгівля тісно пов' язана із гаслом «Кава, цукерки, кола». «Кава» символізує продаж гарячих напоїв, таких як кава, гарячий шоколад, чай, але також супів; термін «цукерки» означає солодощі, а «кола» замінює перелік різних безалкогольних напоїв. На самому початку вендингова індустрія почала 3 концепцією 4 позицій: кава, газована вода, цукерки та сигарети, а пізніше асортимент зріс майже до 8: кава, цукерки чи кондитерські вироби, чіпси, холодні напої, консервовані напої, сигарети та чай.

В Свропі вендинг включає ширший асортимент товарів (EVA, Свропейська асоціація вендингу). Вендингова асоціація в Німеччині (BDV, Bundesverband der Deutschen Vending AutomatenWirtschaft e.V.) визначає вендинг як продаж повсякденних товарів першої необхідності, особливо продуктів харчування та напоїв через торгові автомати [10]. Виробники машин, оператори та різні асоціації використовують термін торг для всіх видів їжі та напоїв, але вони включають і непродовольчі товари.

Австрійська асоціація (ÖVV, Österreichische Verkaufsautomaten Vereinigung) визначає всі машини, що продають товари, включаючи їжу, напої, фотографії, квитки на парковку як торгові автомати; але також включають копіювальні 
машини, телефони, шафки, пральні машини, кульки, ігрові автомати тощо.

Iз точки зору маркетингу торгові автомати визначаються як формат магазину роздрібної торгівлі з автоматичною процедурою продажу - клієнт повинен вибрати товар, взяти його з собою та заплатити за нього.

У США торговий автомат використовує повну скляну фасадну частину, щоб продати товарний асортимент всередині машини. Найчастіше продукт доставляється за допомогою спіралей і дозується в піддон для подачі, розташований внизу машини.

Вендинг визначається як продаж товарів або послуг торговим автоматом, на якому клієнт повинен керувати вибором товару або послуги, забрати товар і вивезти його та заплатити за товар або послуга на місці - готівкою, кредитною карткою або за допомогою інших доступних в електронному вигляді способів оплати, наприклад текстового повідомлення.

На вендинговому ринку можна виділити чотири групи гравців:

- виробники торгових автоматів, аксесуарів та товарів, а також постачальник послуг,
- орендодавці сайту,

- оператор (мерчендайзери та люди, що обслуговують),

- клієнти.

Окрім технічних функцій (енергопостачання, водопостачання, розподіл та платіжна одиниця), при розробці торгових автоматів слід враховувати маркетингові аспекти (наприклад, аксесуари, такі як ложки, чашки, серветки). Враховуючи високі витрати на технічне обслуговування та сильний вплив функціональної ефективності на задоволеність споживачів, технічне обладнання та платіжна система, а також комфорт розподілу дуже важливі. Тому особливості обробки повинні бути ретельно розроблені, особливо для захисту торгових автоматів від вандалізму чи технічних поломок. Огляд можливих станів вендингової системи та переходи між ними наведено на рис. 1.

Товари та аксесуари повинні відповідати як технічним вимогам торгових автоматів (розмір, довговічність, керованість), так і потребам клієнтів (привабливість, просте відкриття, щоб забрати вибрані товари тощо). Упаковка повинна гарантувати, що товар не зламається і не прилипне до спіралі при виборі та доставці.

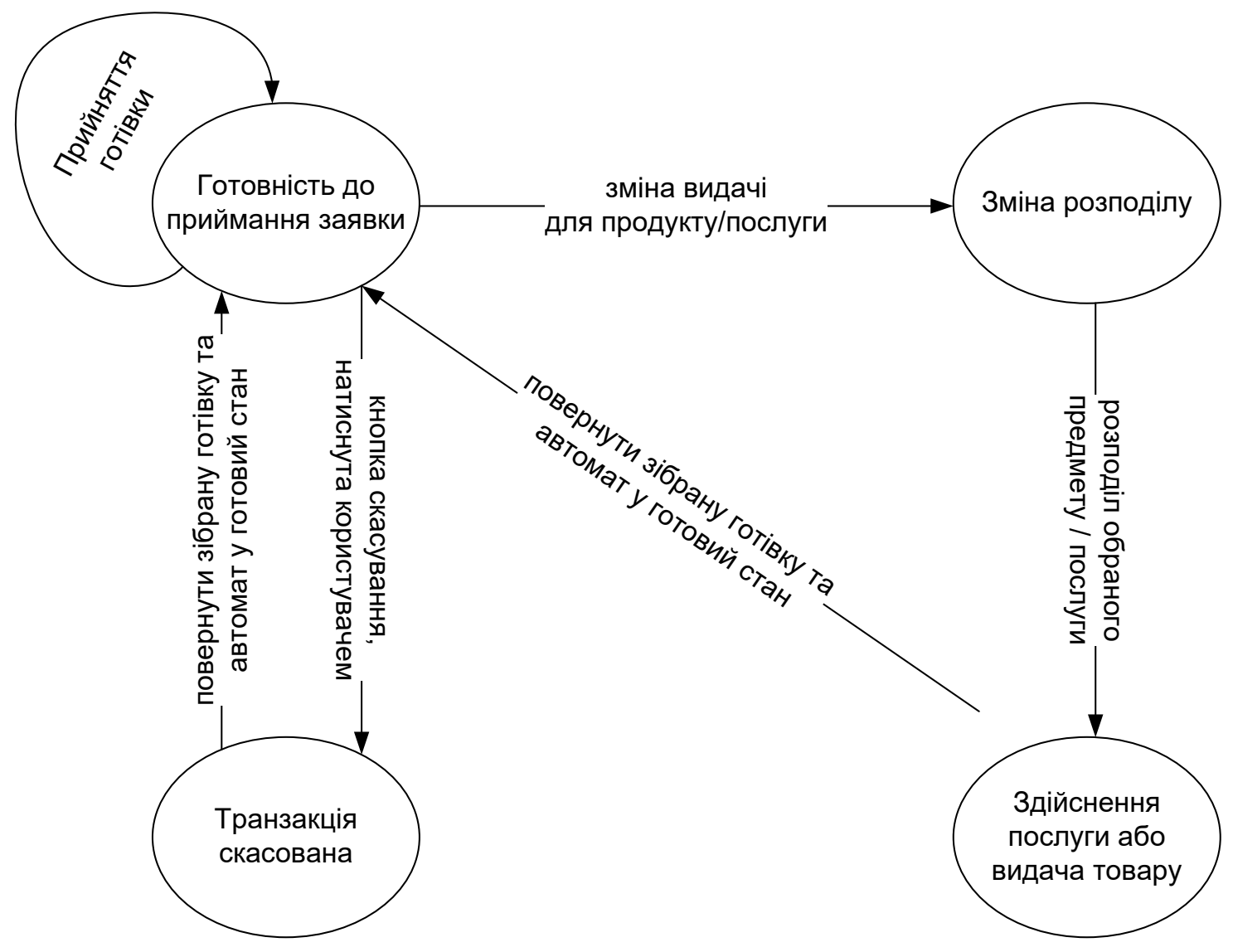

Рис. 1. Переходи між станами вендингової системи 
Оператор повинен стежити за (повторним) наповненням, очищенням та функціональною ефективністю торгового автомата, а також за ефективністю корпусу. Зазвичай оператор збирає асортимент і приймає рішення щодо платіжної системи (готівка, кредитна картка, Інтернет, обмін текстовими повідомленнями тощо).

Оператор повинен знати потреби та ставлення споживачів. Без будь-яких даних про профілі клієнтів, хто купує коли, що, у якій кількості, неможливо зробити висновок з обороту на реальні побажання та потреби клієнтів. Цей брак інформації $\epsilon$ однією з головних проблем вендингового бізнесу. Таким чином, клієнт залишається сам при покупці з торгового автомата, а оператор дуже часто не знає занадто багато про мотиви та ставлення клієнта. Загалом можна стверджувати, що, з точки зору замовника, імідж цього каналу розповсюдження повинен бути покращений.

Орендодавець сайту є власником або орендарем місця, де встановлено торговий автомат. Вiн / вона здає це місце оператору та отримує за це гроші. Зазвичай торгові автомати можна знайти на трьох різних ринках:

- бізнес-ринок (офіс, фабрика, хірургія тощо);

- ринок громадського харчування (ресторан, кафе, кіоск тощо);

- громадський ринок (громадська будівля, школа, університет, торговий центр, спортивний центр, залізничний вокзал, аеропорт, вулиця тощо).

Клієнт вибирає товари 3 торгового автомата, оплачує їх готівкою, кредитною карткою або іншими способами та бере товар 3 підрозділу доставки для подальшого споживання.

Покупка в торговому автоматі може розглядатися як особлива ситуація покупки. Клієнт не може просити про допомогу, і він / вона робить покупку сам без будь-якої поради продавця. Якщо процедура продажу діє добре, клієнта обслуговують досить швидко. У разі виникнення проблеми він / вона повинен з'ясувати, як впоратися із ситуацією. Зазвичай номер телефону оператора пишеться на знаку, який наклеюється на торговий автомат. Тобто клієнт повинен здійснити і оплатити телефонний дзвінок, і в ідеалі проблему можна вирішити негайно. Якщо клієнт хоче поскаржитися на якість товару, комфорт поводження 3 підрозділом доставки або щось інше, спочатку він / вона повинен 3'ясувати, як він / вона може зв'язатися 3 контактною особою. Ситуація 3 покупкою характеризується непрямим спілкуванням, активним пошуком інформації та ризиком покупця піти 3 невирішеною проблемою. 3 іншого боку, конкретна ситуація купівлі також може сприйматися позитивно. Клієнт може вибрати, забрати товар і оплатити, не порушуючи та не маніпулюючи продавцем.

Вендинг - це частина нашого життя. Цілодобово пропонуються різні товари, наприклад фотографії для паспортів, візитних карток, квитків на паркування, презервативи, сигарети, солодощі, їжа, гарячі та холодні напої. На інших вендингових системах є можливість грати у відеоігри, робити копії, прати одяг, телефонувати, грати в азартні ігри тощо.

Вендингові автомати можна класифікувати на орієнтовані на продукцію та сервісні машини. Орієнтовані на товар торгові автомати - це машини, що пропонують як холодну, так і гарячу їжу, а також непродовольчі товари. До цієї категорії належать машини для здійснення пакування, де клієнт надає гроші за товар.

Сервісно-орієнтовані торгові автомати пропонують різні види послуг, розваги (наприклад, музичні автомати, ігрові автомати) та не розваги (наприклад, телефон або послугу зважування).

Референтний дизайн для інтелектуальних вендингів пропонує універсальну архітектуру традиційних торгових автоматів у високопродуктивні, підключені до Інтернету машини. Виробники торгових автоматів можуть використовувати еталонний дизайн для проектування майбутніх машин або для модернізації існуючих. Універсальний дизайн містить кілька апаратних та програмних компонентів, серед яких:

1. Обчислювальна система.

Платформа на базі високопродуктивного процесора із платою Vendor-managed inventory (VMI) замінює традиційні контролери торгових автоматів (VMC), забезпечуючи таким чином машини 3 дротовим Ethernet або широкосмуговим бездротовим підключенням до зовнішнього світу та обчислювальну потужність, необхідну для розгортання нових послуг.

Виробники торгових автоматів можуть вибрати два масштабовані сімейства процесорів, які можуть запускати один і той же код (тобто забезпечуючи зворотну сумісність) і мають технічну підтримку на всіх рівнях реалізації (ISV).

Процесори Intel Core та vPro забезпечують найвищу продуктивність для мультидисплейних та обчислювальних завдань, включаючи цифрові вивіски високої чіткості, аналіз даних та управління вмістом. Вони також підтримують Intel 
Active Management Technology (Intel AMT), можливість віддаленого управління.

Процесори Intel Atom врівноважують обчислювальні та графічні показники, забезпечуючи чудову ціну для торгових автоматів середнього класу.

2. Модуль інтерфейсу вводу-виводу

Сучасні вендингові автомати використовують широкий спектр протоколів шини (наприклад, CAN, ccTalk, MDB, USB) для зв'язку між VMC та периферійними пристроями, такими як механіка управління та пристрої зчитування приміток. Універсальна архітектура сучасного вендингового апарату містить плату VMI, яка підтримує ці інтерфейси вводу-виводу та багато іншого.

Плата вводу-виводу, показана на рисунку $2, \epsilon$ недорогою конструкцією, що забезпечує високий рівень гнучкості вводу-виводу. Перетворення шинного протоколу здійснюється на платі VMI.

3. Програмний стек.

На рисунку 3 показана архітектура програмного забезпечення еталонного дизайну, що абстрагує торговий ввід-вивід, що дозволяє виробникам вендингових автоматів сконцентруватися на додатках високого рівня та на тому, що відображається на екрані. Це досягається за допомогою двох типів
API: API низького рівня (LLAPI) для доступу до певних торгових протоколів вводу-виводу та API високого рівня (HLAPI) для доступу до периферійного типу, не вимагаючи від програмістів знання деталей фактичного пристрою.

LLAPI забезпечує низькорівневий доступ до пристрою, але пов'язаний із ним код, швидше за все, буде конкретним, що ускладнить повторне використання на іншій машині. 3 іншого боку, HLAPI детально описує, як працює тип пристрою, але деталі зв'язку абстрагуються, що дозволяе повторно використовувати програми для інших конфігурацій машини. По суті, HLAPI спрощує написання вендингової програми та може дозволити торговим операторам використовувати одну програму на всьому їх парку машин.

HLAPI також обробляє зміни в протоколах, таких як MDB, і забезпечує додаткову гнучкість для адаптації до незначних змін у протоколах шини, що потрібно, коли виробники периферійних пристроїв відхиляються від стандартних специфікацій. Іншими словами, HLAPI дозволяє виробникам торгових автоматів робити досить прості зміни конфігурації для підтримки протоколів шини, які були модифіковані периферійними постачальниками.

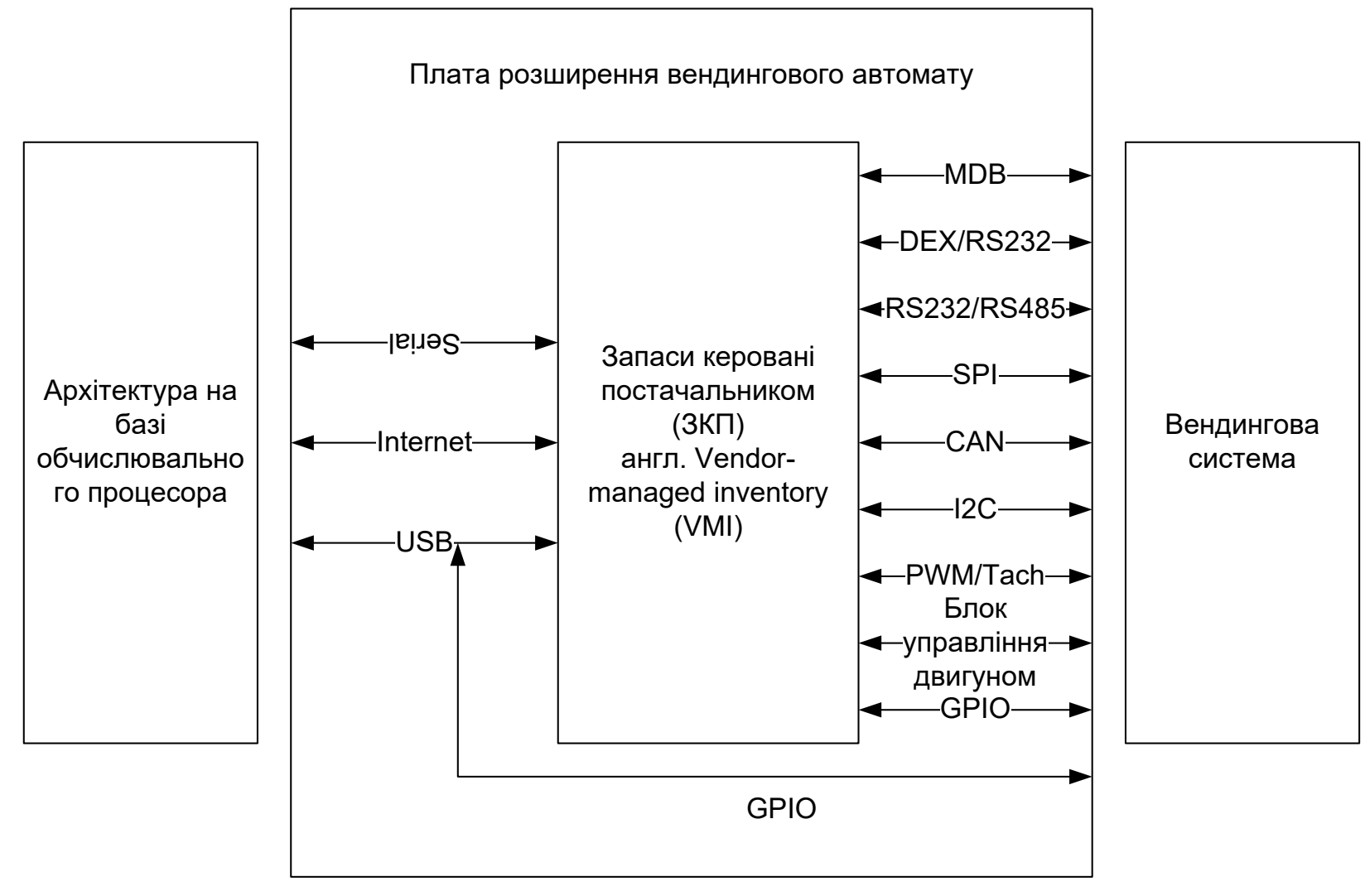

Рис. 2. Плата вводу-виводу вендингового автомату

Джерело: розробка автора на основі [12] 
Інформатика, обчислювальна техніка та автоматизація

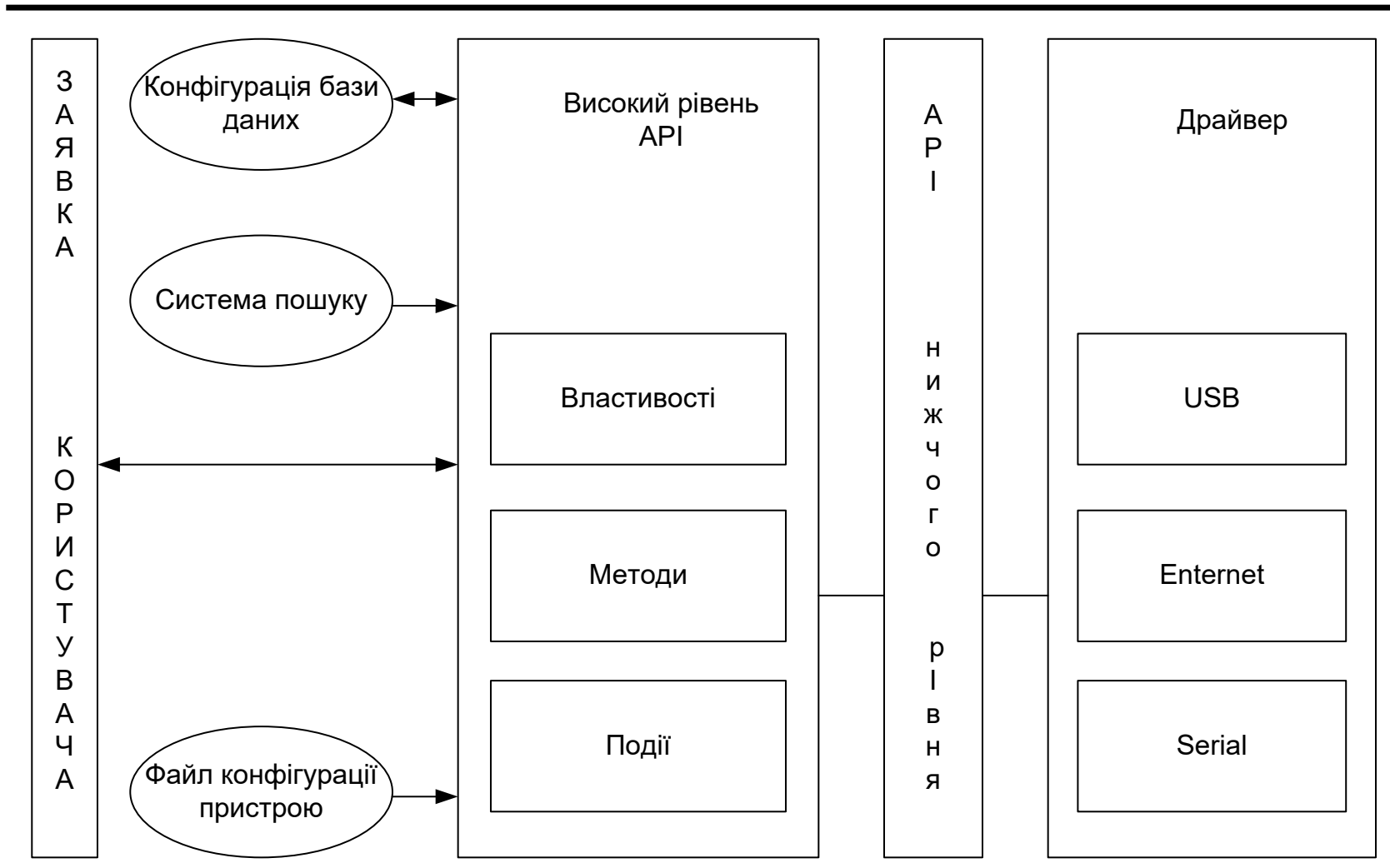

Рис. 3. Програмний стек вендингової системи

Джерело: розробка автора на основі [8]

Забезпечуючи нові бізнес-моделі, безпеку та керованість, цей потужний набір технологій вендингової системи включає в себе:

1) систему управління вмістом (CMS): Менеджер роздрібних клієнтів дозволяє операторам торгових автоматів створювати можливості продажу, складаючи відповідні та високоефективні кампанії за лічені хвилини; не потрібні технічні знання. Повідомлення можна розгорнути на одному екрані або в мережі, а керувати екранами можна незалежно - та віддалено - з одного місця;

2) аналітику: інтегрований в RCM, додатковий набір Audience Impression Metrics Suite (AIM Suite) надає виробникам та операторам цінну інформацію про те, як клієнти торгових автоматів реагують на візуальні повідомлення та як вони взаємодіють 3 машиною. Програмне забезпечення агрегує статистику глядачів за статтю, віковим діапазоном, кількістю показів та часом перебування, інформацію, яку можна використовувати для відтворення рекламних оголошень та вимірювання ефективності кампанії, а також визначає втрачені продажі від клієнтів, які пішли, не зробивши покупки. Це все робиться анонімно.

3) керованість: дозволяє консолі управління IT віддалено контролювати, діагностувати та, в багатьох випадках, віддалено виправляти пошко- джене програмне забезпечення. Якщо торгова система виходить із ладу, попередження, що містить системну діагностику, може бути автоматично надіслане обслуговуючому персоналу, скорочуючи час простою та втрачені можливості продажу;

4) програмне забезпечення для захисту: підтримує цілісність торгових автоматів, дозволяючи запускати лише авторизований код і вносити лише дозволені зміни. Він автоматично створює динамічний білий список «авторизованого коду» в системі. Після створення та ввімкнення білого списку система блокується до відомого хорошого базового рівня, і жодна програма або код поза дозволеним набором не може працювати. Білий список допомагає запобігти виконанню вірусів, шпигунських програм та інших шкідливих програм.

Висновки. У роботі здійснено огляд принципів проектування сучасних вендингових систем, їх структури та архітектурної складової. Спектр вендингових автоматів масштабний, очікується подальший технологічний розвиток на вендинговому ринку. Швидкий розвиток торгових автоматів та зменшення соціальних контактів між продавцем та покупцем відображає два типи змін у нашому суспільстві: з одного боку, технічні досяг- 
нення, які дозволяють пропонувати нові види продукції та забезпечують безпеку як продавця, так і клієнта, з іншого боку, потреби споживачів змінюються. Дієва відкрита архітектурна складова сучасної вендингової системи повинна забезпе- чувати виконання потреб клієнтів та буди універсальною.

Перспективи подальших досліджень базуються на розробці моделі вендингової системи 3 вдосконаленим модулем обробки запитів клієнтів.

\section{Список літератури:}

1. Сало А.М. Принцип побудови вендінгової мережі з моніторингом. Вісник Нац. ун-ту «Львівська політехніка» «Комп'ютерні системи та мережі». Львів, 2013. № 773. С. 112-118.

2. Сало А.М., Загорняк В.В. Засоби оптимізації модуля адміністрування вендингових кіберфізичних систем. Вісник Національного університету «Львівська політехніка». Серія: Комп 'ютерні системи ma мережі. Львів : Видавництво Національного університету “Львівська політехніка", 2018. № 905. C. $117-124$.

3. Горбаль Н.І. Келлер 3.Ю., Найчук-Хрущ М.Б. Вендинговий стартап на українському ринку. Науковий вісник НЛТУ Украӥни. Серія економічна. 2017. Вип. 27(2). С. 53-57.

4. Котвицький О.Л. Модуль безготівкової оплати для систем самообслуговування / Національний Університет «Львівська Політехніка», кафедра електронних обчислювальних машин. URL : http://eom.lp.edu. ua/sntk/doc/ksm2020/kotvitskiy.pdf (дата звернення: 17.09.2020).

5. Design of a high-tech vending machine / Vennan Sibanda, Lorraine Munetsib, Khumbulani Mpofua, Eriyeti Murenaa, John Trimblea / 30th CIRP Design 2020 (CIRP Design 2020). URL : https://pdf.sciencedirectassets. com/282173/1-s2.0-S2212827120X00096/1-s2.0-S2212827120308829/main.pdf?X-Amz-Security-.

6. Lee E. A. and Seshia S. A. Introduction to Embedded Systems - A Cyber-Physical Systems Approach, Second Edition, MIT Press, 2017. P. 9-16.

7. Hua S.V., Ickovics J.R. Vending machines: a narrative review of factors influencing items purchased. Journal of the Academy of Nutrition and Dietetics. 2016. Vol. 116(10). P. 1578-1588.

8. Gruber S. The commodity vending machine', IGWT Internationale Gesellschaft für Warenwissenschaften und Technologie. 2016. P. 1-11.

9. Donald W. Howell. Vending mashine monitoring system. URL : http://patent.ipexl.com.

10. Sheet, F. Vending Machines and Other Coin-Operated Devices, (2800158). 2017. P. 1-4.

11. Ltd G. V. In-Cup Hot Drinks - Table Top Vending Machine - GEM Vending. 2018.

12. Howard K., Davidson G., inventors; Cloverleaf Media Llc, assignee. Digital signage device. United States patent application US 29/542,226. 2017.

\section{Chernyshov K.A., Maidaniuk V.P., Arseniuk I.R. DESIGNING PRINCIPLES OF MODERN VENDING SYSTEMS}

The principles of designing modern vending systems are revealed. The genesis of vending machines is proposed and the types of their application are described. The main types of vending machines and their equipment are given. The principles of application of vending systems in different countries of the world are described. An overview of possible states of the vending system and transitions between them is offered. The universal design of a modern vending machine is characterized, in which hardware and software components are separated. The importance of operator management is emphasized and a list of basic actions is proposed, such as: monitoring the (re) filling, cleaning and functional efficiency of the vending machine, as well as the efficiency of the case, assembling the range and deciding on the payment system. The scheme of the I/O board of the vending machine with the separation of the fundamental components is given. The connection links between the components inside the vending machine expansion board have been identified. The software stack of the vending system is schematically presented, which gives a clear idea of the functional component of the vending system. The architecture of the reference design software abstracts commercial I / O, allowing vending machine manufacturers to focus on high-end applications and what is displayed on the screen. It is noted that this fact is achieved through two types of APIs: low-level API for access to certain trade I / O protocols and high-level API for access to peripheral type, without requiring programmers to know the details of the actual device. It is emphasized that the high level of API simplifies the writing of the vending program and can allow retailers to use a single program throughout their fleet, as well as process changes in protocols such as MDB, and provide additional flexibility to adapt to minor bus protocol changes when peripheral manufacturers deviate from standard specifications.

Key words: vending, system, management, monitoring, Internet of Things, controller, protocol. 